\title{
THE IMPORTANCE OF RESEARCH FOR COUNTY MUSEUMS
}

Joakim Wehlin

Dalarnas museum

Box 22, 79121 Falun, Sweden

joakim.wehlin@dalarnasmuseum.se

The demand for knowledge often goes hand in hand with qualified research work. However, many museums base their work on previously conducted research, since no or very little research work is performed by the museums themselves.

Few Länsmuseer (county museums) today employ archaeologists who are not in part developer-funded. On the contrary, a common situation is that contract archaeology enables many museums to retain their qualified archaeological staff. This is a circumstance that I consider a problem. The focus is on specific assignments, which may indeed include communicative work as well as research. Nevertheless, the areas to be studied are chosen by the market, that is to say, the developer. Lacunas in the research are thus only studied in exceptional cases.

Archaeology is essentially a scientific subject, one of the oldest university disciplines. During a large part of the twentieth century, many of the museums were classified as learned institutions. They were included in the educational system and an unquestionable part of museum work therefore included extensive research work on the subjects represented at the museums. Among the public, Länsmuseerna stood for qualita- 
tive knowledge about the regional cultural history, and an important part of this was archaeology.

These museums used to have a distinct research basis in their work, but today this has generally become rare. It is of vital importance to return to this basis, otherwise the quality of knowledge at the museums tends to become watered down.

\section{THE CRUCIAL ROLE OF LÄNSMUSEER}

In Sweden, there are three general categories of museums. There are state-owned central museums, Länsmuseer and a heterogeneous group of other museums. The latter group covers a wide spectrum including larger national museums and smaller local museums. Central museums and Länsmuseer have specific assignments and responsibilities.

Länsmuseer developed during the early twentieth century as a way of extending state heritage management throughout the country (SOU I922:II-I2 Betänkande med förslag till lag angående kulturminnesvard samt organisation av kulturminnesvarden I922). The state contributed funding and civil servants, who soon found local funding, and the museums grew to become important institutions for knowledge. In the post-war period, the organization of the museums was restructured into trusts. The trustees were municipalities and county councils, often in collaboration with regional heritage societies. During the I970s, Swedish museum organization was transformed. In the new model, the function of Länsmuseer was to act as advisors in the planning work of the municipalities. This work included surveys, providing knowledgeable information, care and restoration, but also performing certain assignments included in the heritage management of the state. This is a responsibility of these museums that is still carried out jointly with Länsstyrelsen (the County Administrative Board). The exact nature of this collaboration varies to a certain extent from region to region (SOU 2015:89 Ny Museipolitik: Betänkande av Museiutredningen 20I4/I5 2015; Prop. 20I6/I7:116 Kulturarvspolitik 2017).

Länsmuseerna carry a tradition that is vital in this context, not least with reference to the local connection. This is a question advocated by Länsmuseernas samarbetsråd (The Collaboration Council of the County Museums) through the slogan Sweden's Largest Museum (Länsmuseernas samarbetsråd n.d.). Central museums are chiefly located in the main cities of Sweden (Stockholm and Gothenburg), while Länsmuseerna act as arenas across the country for management of cultural and social questions. For many Swedes, Länsmuseet of their own 
region is the first that comes to mind, both as a museum and as a source of knowledge. The museum stands for reliability and trustworthiness, providing many with a channel to gain knowledge about the outcome of research, presented in an accessible way.

The trustworthiness of the museums is based on a link to research that was a natural part of the work during the second half of the twentieth century. At Länsmuseerna, there were research councils and formulated research programmes. Dalarna's Museum was a good example; the director of the museum then in office expressed himself as follows: 'A meaningful and socially based cultural policy needs continual research, which adds fuel, new knowledge, new ideas and new values' (translated here, Hofrén 1974). In the case of the museum of Dalarna, the research work was taken over by the county council and was to a greater degree oriented towards the public sector, which most likely also occurred in other parts of the country. This meant that, over the years, questions that were specific for the museums were left behind, which to my mind is a problem.

\section{RESEARCH AT MUSEUMS TODAY}

A few years ago, a survey of research at Swedish museums was conducted (Lihammer 2009). The project provided a concise overview of the research, the researchers and the conditions under which they work. The situation differs among the museums, but there are certain tendencies in common.

For example:

- The knowledge used at the museums is often based on research from the middle of the twentieth century or earlier.

- Research that is conducted today is often based on external projects, often with a weak link to the knowledge requirements of the museum.

- Questions that the museums need to research are not treated by academic research.

- Too few among the staff of the museums have a doctoral degree and their duties do not allow time for research work, or even time to formulate research projects.

- However, the scientific quality of the work and the qualifications of the staff are high. There is also a consensus that research is a necessary part of the work and future of these institutions. 
- The infrastructure of research is poor at the museums. Research work is conducted, but quite often there is a lack of research coordination, research programmes, research councils, scientific reference groups and strategic collaboration.

The situation seems to be turning the right way since the report about research at museums was published. For example, a network named FOMU - research at museums, has been established during the past couple of years. The network acts to support research at museums and thereby also to develop museums as well as the research sector. Many of Länsmuseerna have been assessing their work and organization, not least to be able to meet budgets that are gradually getting tighter. The research basis, however, is still pointed out as an important part of the work. Several of the museums, among others Dalarna's Museum and lately Gotland's Museum, clarify the importance of a research basis when reworking their strategic agenda.

\section{A RESEARCH BASIS IS THE FUTURE}

New assignments have been allocated to the museums. This is, for example, expressed by the government when stating that the cultural heritage should be everybody's concern, that public debate should be broadened and given more depth and that public co-creation and involvement should be encouraged. The main purpose of the museum regulation that came into effect in August 2017 (SFS 2017:563 Museilag 2017) is to 'strengthen the independence of the institutions, and their status as institutions of knowledge' (translated here, Prop. 2016/17:1 16 Kulturarvspolitik 20I7). This requires improved competence and partially a new direction for museum production. The Museum Act $\$ 8$ states that: 'A museum should contribute to research and other accumulation of knowledge, among other ways by maintaining a high standard of competence within its field of knowledge' (translated here, SFS 2017:563 Museilag 2017).

However, a more substantial research basis at museums requires increased collaboration with universities, greater possibilities to apply for funding, with calls for proposals open for all museums (not only state museums), research that is relevant to the work of the museum, a greater number of staff members with doctoral degrees, but there should also be an explicit state requirement for research to be conducted at museums. By participating actively in research, museums can strengthen their scientific perspective and build up their trustworthiness. The scientific 
quality of the generated knowledge will increase. Employing staff with $\mathrm{PhD}$ qualifications opens up for possibilities of applying for research funding and collaborating with other parties involved in research work.

To meet this challenge, it would be interesting, for example, to create a research programme for the museum sector. Such a programme could be specifically oriented towards museum staff for conducting doctoral studies but also for already qualified $\mathrm{PhD}$ staff. This would reinforce the museums' scientific standing, although first and foremost it would strengthen their role as independent institutions in the pursuit of knowledge.

\section{REFERENCES}

Betänkande med förslag till lag angående kulturminnesvård samt organisation av kulturminnesvarden. 1922. Statens offentliga utredningar I922:I I-I2. Stockholm.

Hofrén, E. (Ed.). 1974. Att välja forntid: [lägesrapport]. Falun: Dalarnas museums forskningsråd.

Kulturarvspolitik. 2017. Regeringens proposition 20I6/I7:I I6. Stockholm: Riksdagen.

Lihammer, A. 2009. Forskningen vid svenska ABM-institutioner: En undersökning av aktuella förutsättningar och trender. Stockholm: Nobel Museum.

Museilag. 20I7. Svensk författningssamling 20I7:563. Stockholm: Kulturdepartementet.

Ny Museipolitik: Betänkande av Museiutredningen 20I4/I5. 20I5. Statens offentliga utredningar 2015:89. Stockholm: Wolters Kluwer.

\section{Internet resources}

Länsmuseernas samarbetsråd. n.d. [online] Availible at: <http://www.länsmuseerna. se> [Accessed I8 September 2017].

Sverige museer. n.d. Forskning vid museer (FOMU): Programförklaring. Karlskrona: Sverige museer. [online] Availible at: <http://www.sverigesmuseer.se/wp/wpcontent/uploads/20I5/I I/Programforklaring.pdf> [Accessed I8 September 20I7]. 